\title{
Acute Retropharyngeal Calcific Tendonitis as a Rare Cause of Odynophagia and Neck Pain
}

\author{
Odinofaji ve Boyun Ağrısının Nadir Bir Nedeni Olarak Akut \\ Retrofarengeal Kalsifik Tendonit
}

\author{
Prempreet Kaur Manjit SINGH $\odot$, Muhammad Irsyad Mohamed NOOR $\odot$, Rohaizam JAAFAR $\odot$, \\ Amali AHMAD $\odot$, Irfan MOHAMAD $\odot$
}

Ethics Committee Approval: Not Applicable.

Conflict of interest: The authors declare that they have no conflict of interest.

Funding: None.

Informed Consent: Informed consent was taken.
Cite as: Singh PKM, Noor MIM, Jaafar R, Ahmad A, Mohamad I. Acute Retropharyngeal Calcific Tendonitis as a Rare Cause of Odynophagia and Neck Pain. Medeni Med J. 2021;36:75-9.

\begin{abstract}
Retropharyngeal calcific tendonitis (RCT) is an aseptic inflammatory process of the superior oblique tendons of the longus colli muscle caused by the deposition of calcium hydroxyapatite crystals. We reported a 23-year-old woman who presented with a sudden onset of neck pain with odynophagia after waking up from sleep. Physical examination showed paracervical point tenderness with limited neck movement in all directions. Prior to surgery, further imaging was requested to aid in diagnosis, which in turn revealed RCT. It is important to be aware that RCT presentation may mimic other severe conditions such as retropharyngeal space abscess or meningitis.
\end{abstract}

Keywords: Retropharyngeal calcific tendonitis, longus colli tendon, trismus, calcium hydroxyapatite crystal

öz

Retrofarengeal kalsifik tendinit (RCT), kalsiyum hidroksiapatit kristalleri birikmesinin neden olduğu longus colli kasının üst oblik tendonlarının aseptik enflamatuar bir sürecidir. Uykudan uyandıktan sonra odinofaji ile birlikte ani başlayan boyun ağrısı ile bize başvuran 23 yaşındaki bir kadın vakasını sunuyoruz. Fizik muayenede, her yöne sınırlı boyun hareketi ile birlikte para-servikal nokta hassasiyeti görülmüştür. Ameliyattan önce, tanıya yardımcı olmak için daha fazla görüntüleme istenmiştir ve RCT ortaya çıkmıştır. RCT sunumunun retrofaringeal boşluk apsesi veya menenjit gibi diğer ciddi durumları taklit edebileceğinin farkında olmak önemlidir.

Anahtar kelimeler: Retrofarengeal kalsifik tendinit, longus colli tendon, trismus, kalsiyum hidroksiapatit kristali
Received: 3 December 2020

Accepted: 21 January 2021

Online First: 26 March 2021

Corresponding Author:

I. Mohamad

ORCID: 0000-0001-8572-0514

Universiti Sains Malaysia,

School of Medical Sciences, Department of OtorhinolaryngologyHead and Neck Surgery, Kelantan, Malaysia

irfankb@usm.my

P.K.M. Singh

ORCID: 0000-0003-4165-8311 Universiti Sains Malaysia, School of Medical Sciences, Department of OtorhinolaryngologyHead and Neck Surgery, Kelantan, Malaysia

M.I.M. Noor

ORCID: 0000-0002-4089-338X Hospital Kuala Lumpur, Department of OtorhinolaryngologyHead and Neck Surgery, Kuala Lumpur, Malaysia

R. Jaafar

ORCID: 0000-0001-6530-453X Hospital Kuala Lumpur, Department of OtorhinolaryngologyHead and Neck Surgery, Kuala Lumpur, Malaysia

A. Ahmad ORCID: 0000-0003-2679-1974 Hospital Kuala Lumpur, Department of Radiology, Kuala Lumpur, Malaysia 


\section{INTRODUCTION}

Acute retropharyngeal calcific tendinitis (RCT), also called acute calcific prevertebral tendonitis, is a less known condition that causes pain and neck stiffness associated with odynophagia ${ }^{1}$. Clinical examination frequently mimics a retropharyngeal abscess. Radiographically, it manifests as calcium deposits and edema of the retropharyngeal soft tissues ${ }^{1}$. Its formation mechanism has not been fully understood, however, RCT is usually a selflimiting condition, often resolving within one to two weeks ${ }^{2}$.

The hypotheses of the disease are said to be due to chronic trauma to the neck, tendinous degeneration and aseptic inflammation secondary to response to the calcium phosphate deposition in the longus colli muscle ${ }^{3,4}$. In clinical practice, clinicians often have the suspicion of retropharyngeal abscess prior to ruling out RCT. The management of both conditions vary significantly. Further imaging aided us to narrow down the diagnosis and initiate treatment accordingly. In our patient, diagnosis was made after imaging studies were completed. We highlighted this case so that clinicians would also rule out RCT in patients presenting with such symptoms so as to avoid unnecessary invasive procedures such as biopsy or incision and drainage.

\section{CASE REPORT}

A 23-year-old woman presented with three days history of odynophagia and neck pain, exacerbated by food intake and neck movement. There was no history of strenuous activity or trauma. She had no fever, neck swelling, cough, hoarseness, shortness of breath or vomiting. There was no significant medical or surgical history.

On general examination, the patient was afebrile. The neck pain was aggravated on passive neck movements towards all directions. The paracervical region was tender on palpation. There was no neck swelling yet a two-finger-breath trismus was present. Intraoral examination was unremarkable.

Flexible nasopharyngolaryngoscopy revealed a bulging posterior pharyngeal wall from the level

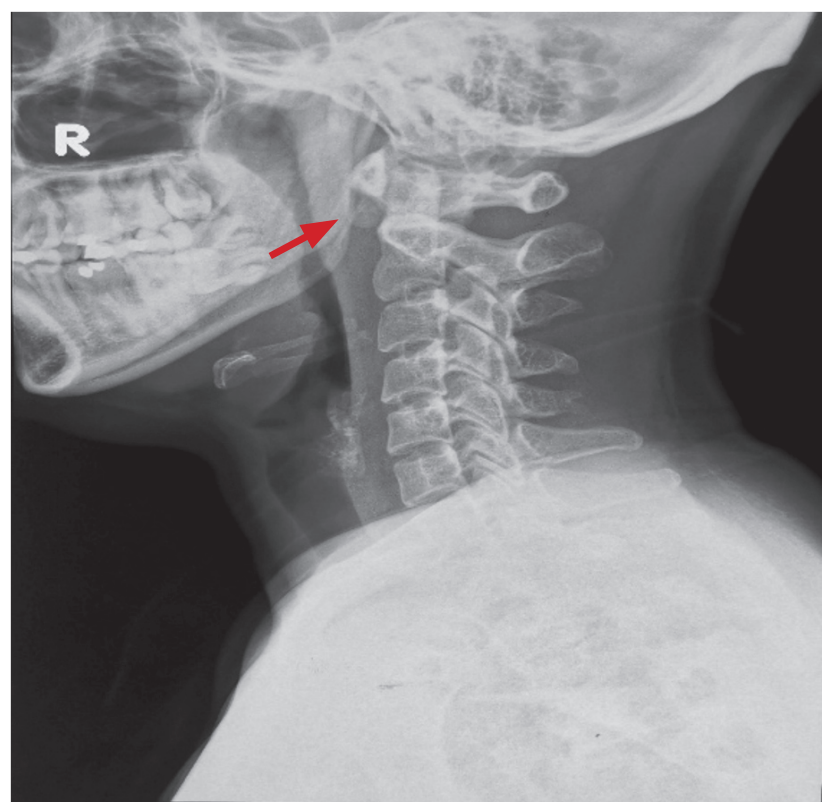

(a)

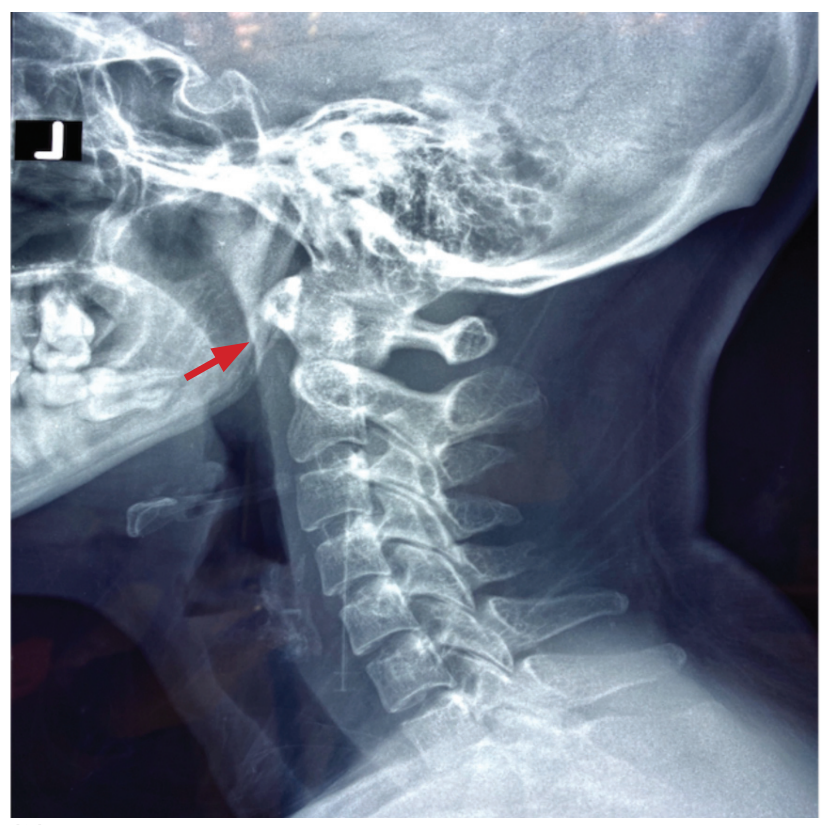

(b)

Figure 1(a). Cervical pretreatment radiogram shows loss of cervical lordosis with abnormal prevertebral thickening at $\mathrm{C} 1$ and $\mathrm{C2}$ levels. Arrow shows soft tissue calcification anterior to $C 1$ and $C 2$ levels. (b): Lateral cervical post-treatment radiogram shows resolution of soft tissue calcification. 
of nasopharynx to oropharynx. The overlying mucosa appeared normal. Leukocyte count was normal. Erythrocyte sedimentation rate (ESR) was

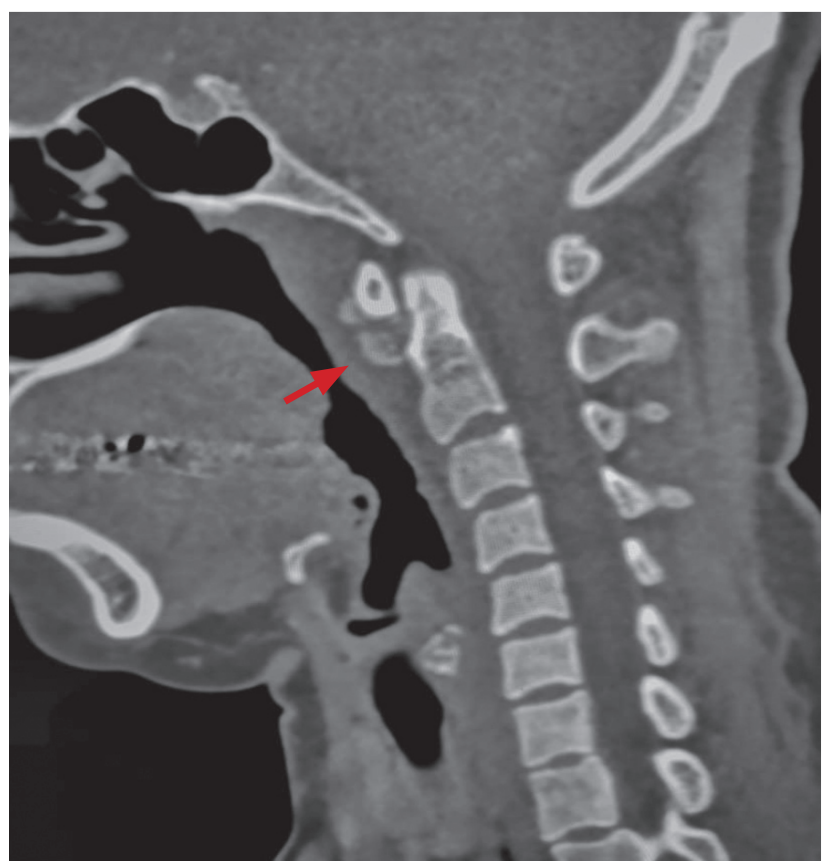

(a)

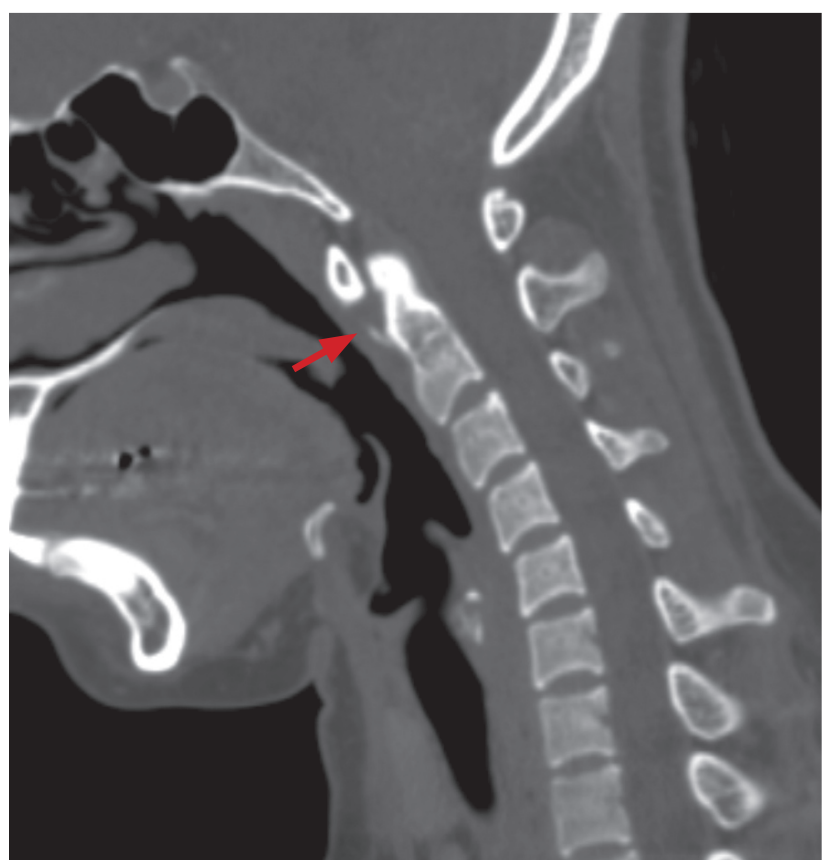

(b)

Figure 2(a). CT scan of neck (sagittal view) showing loss of cervical lordosis with soft tissue thickening at $\mathrm{C} 1$ and C2 levels. Arrow shows soft tissue calcification anterior to $C 1$ and C2 levels. (b): CT scan of neck (sagittal view) showing resolution of retropharyngeal/prevertebral soft tissue edema with minimal residual soft tissue calcification anterior to $\mathrm{C} 1$ and $\mathrm{C2}$ levels. raised to $40 \mathrm{~mm} / \mathrm{hr}$. A provisional diagnosis of retropharyngeal abscess was made.

Due to the initial suspicion of foreign body in the throat by the Emergency Department, a cervical

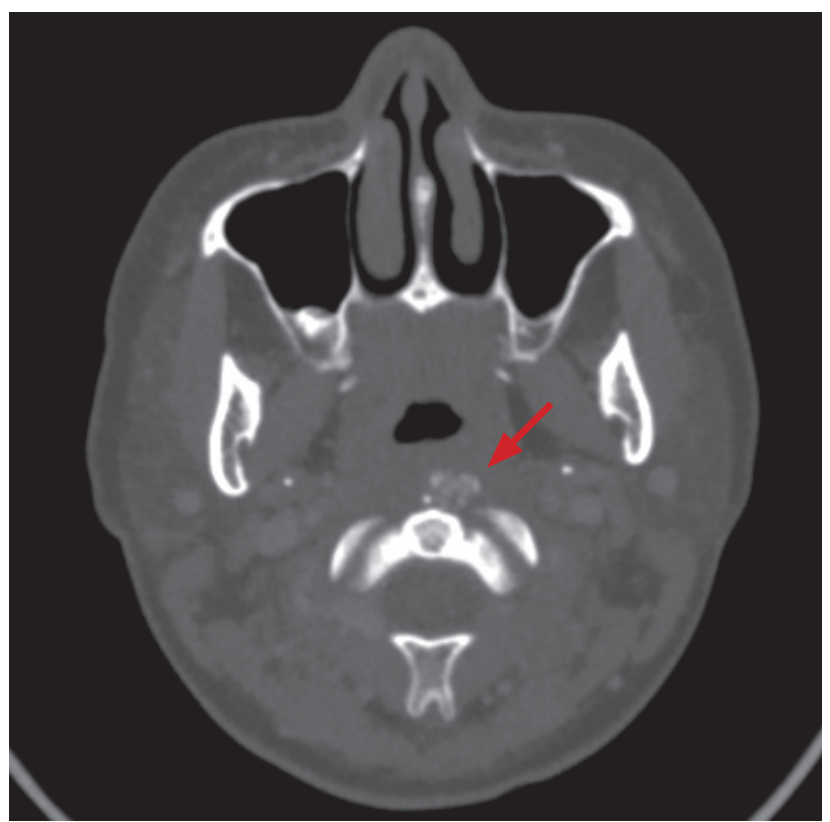

(a)

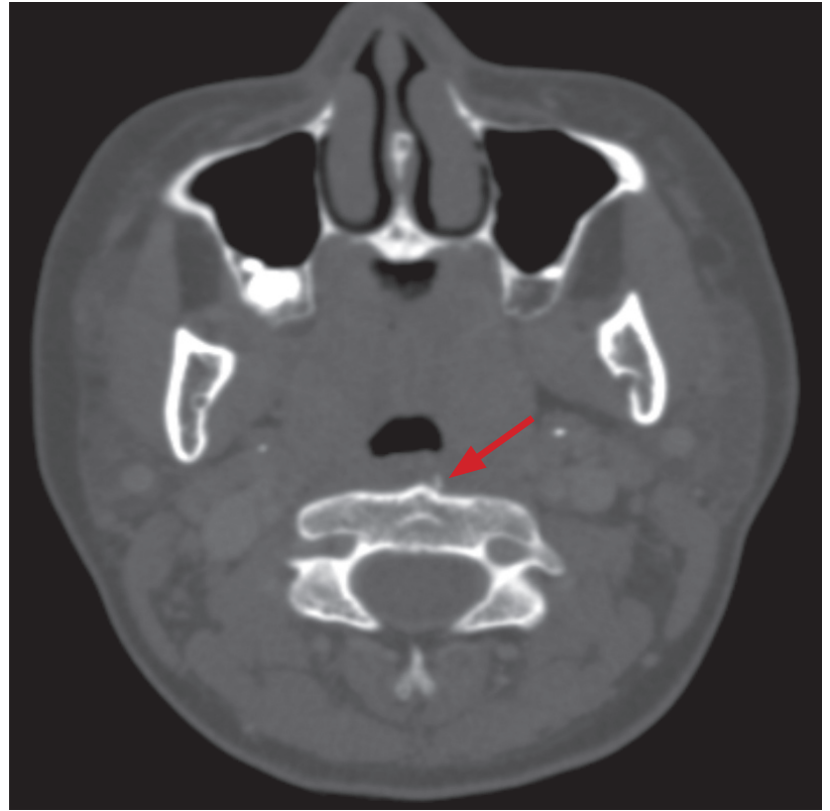

(b)

Figure 3(a). CT scan of neck (axial view) showing focal prevertebral soft tissue thickening at $\mathrm{C}_{1}$ and $\mathrm{C}_{2}$ levels measuring one $\mathrm{cm}$ in full thickness. Arrow shows soft tissue calcification anterior to $C 1$ and C2 levels. (b): CT scan of neck (axial view) shows reduced soft tissue thickening at $\mathrm{C} 1$ and $\mathrm{C} 2$ levels measuring $0.5 \mathrm{~cm}$. 
X-ray was performed that showed loss of cervical lordosis with an abnormal prevertebral thickening seen at C1 and C2 levels (Figure 1a). Then, we proceeded with computed tomography (CT) of the neck, which revealed a focal prevertebral soft tissue thickening at $\mathrm{C} 1$ and $\mathrm{C} 2$ levels measuring one $\mathrm{cm}$ in full thickness (Figures $2 \mathrm{a}$ and $3 \mathrm{a}$ ). The calcification extended into the atlantodental joint space. There was no rim-enhancing collection or air pockets at the prevertebral or retropharyngeal space to suggest an abscess. The diagnosis was then revised to RCT.

Our patient received adequate analgesia (paracetamol and tramadol) in addition to empirical antibiotics (cefuroxime and metronidazole) for presumed retropharyngeal abscess despite the impression of acute RCT obtained from the CT scan. The antibiotics were initiated prior to obtaining CT scan results, and maintained keeping in view of the infective causes as the commoner etiology of such presentations. Her symptoms improved gradually and resolved five days after the admission.

Two months later, lateral cervical radiograph and CT scans were repeated (Figures $1 \mathrm{~b}, 2 \mathrm{~b}$ and $3 \mathrm{~b}$ ), which showed resolution of retropharyngeal/prevertebral soft tissue edema with minimal residual soft tissue calcification anterior to the odontoid process. The ESR reduced to $20 \mathrm{~mm} / \mathrm{hr}$, indicating recovery.

\section{DISCUSSION}

RCT, also known as calcific tendinitis of the longus colli muscle, is a rare benign self-limiting inflammation of the longus colli tendon with calcium hydroxyapatite deposition ${ }^{2,5}$. The function of longus colli muscle is to flex and rotate the neck ${ }^{6}$. It consists of upper (superior), lower (inferior), and central (vertical) tendons ${ }^{7,8}$. RCT commonly affects the superior tendon of longus colli muscle which inserts onto anterior tubercle of $\mathrm{C} 1$ vertebra, also known as atlas ${ }^{6}$.
RCT affects adults between fourth to eighth decades of life, but is also commonly seen in adults aged between 30 and 60 years old ${ }^{2,5}$. Some studies do mention the female preponderance, despite this is not being an usual observance in clinical practice ${ }^{2,9}$. Patients usually present with acute onset of severe neck pain, dysphagia, odynophagia, neck stiffness or low-grade fever $2,5,8,9$. On the other hand, retropharyngeal abscess presents with symptoms mimicking RCT, including fever, odynophagia, and torticollis with bulging posterior wall of oropharyn $x^{10}$. Other differential diagnoses include pharyngitis, epiglottitis, parapharyngeal space infection or even cervical spine-related problems, such as epidural abscess, osteomyelitis or diskitis.

Just like many other cases reported on RCT, most clinicians will preliminarily diagnose their patients as having retropharyngeal abscess due to similar presenting symptoms. Fearing poor prognosis of untreated retropharyngeal abscess, empirical antibiotics are usually commenced. However, RCT patients generally would show no improvement with antibiotic therapy. Nevertheless, a clinician should also contemplate other differential diagnoses such as meningitis, pyogenic spinal infection, disc herniation or cervical myopathy ${ }^{5,9}$. This is why further imaging such as CT plays a major role in diagnosing RCT. RCT is often diagnosed as an incidental finding during CT scan that shows swollen prevertebral soft tissue with calcification to $\mathrm{C} 1$ and $\mathrm{C} 2$ levels.

Due to limited resources, some institutions still rely on the classical X-ray findings of calcification rather than performing a CT scan. Unfortunately, radiograms commonly show soft tissue edema instead, due to the inflammatory process ${ }^{11}$. A contrasted CT scan is the gold standard to identify existence of a prevertebral edema and calcium deposits on superior oblique muscle which is commonly seen from level $\mathrm{C} 2$ until $\mathrm{C} 5^{2,5,9}$. On the other hand, magnetic resonance imaging (MRI) would show a fusiform effusion and prevertebral 
soft tissue swelling with muscle edema which can be visualized by MRI, however MRI has poor sensitivity to detect calcification ${ }^{6,12}$.

There are few hypotheses on the pathophysiology of RCT. Severe pressure or repetitive trauma to neck, presence of connective tissue disorder, and degenerative spinal or tendinous disorder lead to the accumulation of calcium hydroxyapatite crystals in the muscles ${ }^{9,11}$. However, there may not be any triggering factor in certain cases, as seen in our patient, who had no risk factors at all ${ }^{11}$. Some literature reported rupture of the calcium crystals causing aseptic foreign body type of inflammation, which results in formation of reactive fluid in retropharyngeal space? ${ }^{9}$ Typically, they cause an elevated ESR and leucocytosis. In our patient, the leucocyte count was within the normal range, which could have been contributed to the oral antibiotics administered prior to hospital admission.

RCT is a self-limiting disease, whereby pain peaks from two to five days and symptoms resolve within one to two weeks ${ }^{2}$. This is supported by the fact that calcium resorption usually takes place within one to two weeks which may be seen on post-recovery images ${ }^{6}$. A repeated CT scan one month after the treatment will show disappearance of both calcification and soft tissue swelling. Nonsteroidal anti-inflammatory drugs (NSAIDS), steroids, and opiates are the mainstay of treatments that help to ease patients' symptoms by reducing the inflammation, 2,5,6,11 . A soft cervical collar may be used to immobilize the neck to prevent aggravation of the symptoms ${ }^{9}$. A study done many years ago with 12 cases of RCT, noted only one case had two attacks within two years ${ }^{12}$. Therefore, the incidence of recurrent attacks is rare in RCT.

\section{CONCLUSION}

Even though RCT is rare, clinicians should be aware of its diagnosis and consider it as a differ- ential diagnosis for symptoms such as sudden onset of neck pain, odynophagia, neck stiffness, restricted neck movement or trismus. In centers where imaging is readily available, a CT scan should be performed to confirm the diagnosis to initiate a prompt treatment. Radiological imaging can help to avoid unnecessary and dangerous interventions that may lead to serious adverse events. A prompt diagnosis of RCT helps to relieve symptoms sooner, thus reduces the duration of hospital stay.

\section{REFERENCES}

1. Gallego-Goyanes A, Anta-Martinez L, Pino-Minguez J. Acute retropharyngeal calcific tendinitis or calcium hydroxyapatite deposits in longus colli muscle. J Med Cases. 2017;8(2):63-6. [CrossRef]

2. Zapolsky N, Heller M, Felberbaum M, Rose J, Steinberg E. Calcific tendonitis of the longus colli: an uncommon but benign cause of throat pain that closely mimics retropharyngeal abscess. J Emerg Med. 2017;52(3):358-60. [CrossRef]

3. Tamm A, Jeffery CC, Ansari K, Naik S. Acute prevertebral calcific tendinitis. J Radiol Case Rep. 2015;9(11):1-5. [CrossRef]

4. Raggio BS, Ficenec SC, Pou J, Moore B. Acute calcific tendonitis of the longus colli. Ochsner J. 2018;18(1):98100. Available from: https://www.ncbi.nlm.nih.gov/ pmc/articles/PMC5855435/

5. Yaylacı S, Öztürk TC, Aksoy E, Koçyigit A, Yılmaz A, Karaarslan E. Retropharyngeal calcific tendinitis: report of two cases. J Emerg Trauma Shock. 2015;8(2):119-20. [CrossRef]

6. Martindale JL, Senecal EL. Atraumatic neck pain and rigidity: a case of calcific retropharyngeal tendonitis. Am J Emerg Med. 2012;30(4):636.e1-2. [CrossRef]

7. Sinnatamby C. Last's anatomy regional and applied. 12 th ed. Churchill Livingstone Elsevier; 2011.

8. Razon RV, Nasir A, Wu GS, Soliman M, Trilling J. Retropharyngeal calcific tendonitis: report of two cases. J Am Board Fam Med. 2009;22(1):84-8. [CrossRef]

9. Zibis AH, Giannis D, Malizos KN, Kitsioulis P, Arvanitis DL. Acute calcific tendinitis of the longus colli muscle: case report and review of the literature. Eur Spine J. 2013;22(Suppl 3):S434-8. [CrossRef]

10. Harkani A, Hassani R, Ziad T, et al. Retropharyngeal abscess in adults: five case reports and review of the literature. Scientific World Journal. 2011;11:1623-9. [CrossRef]

11. Naik PP, Poduval J, Divakaran S. Review article: retropharyngeal abscess-mimickers and masqueraders. Indian J Otolaryngol Head Neck Surg. 2017;69(2):269-73. [CrossRef]

12. Jiménez S, Millán JM. Calcific retropharyngeal tendinitis: a frequently missed diagnosis: case report. J Neurosurg Spine. 2007;6(1):77-80. [CrossRef] 